\title{
ОБ'СКТ ПРАВОПОРУШЕННЯ У ВИДІ НЕВИКОНАННЯ ЗАКОННИХ ВИМОГ ПОСАДОВИХ ОСІБ ОРГАНІВ ДЕРЖАВНОӤ ПОДАТКОВОї СЛУЖБИ УКРАЇНИ
}

\author{
ЯРМОЛЕНКО Олександр Сергійович - здобувач Донецького юридичного \\ інституту МВС України \\ DOI:10.32782/EP.2020.2.6 \\ УДК 351.086
}

Статтю присвячено визначенню об'єкта правопорушення у виді невиконання законних вимог посадових осіб органів Державної податкової служби Украйни. Відмічається, що чинне адміністративне законодавство? крім визначення поняття адміністративного правопорушення (cm. 9 КУпАП) не виділяе об'єктивних ознак адміністративного правопорушення. Проте із визначення поняття адміністративного правопорушення можна зробити висновок, що обов'язковими ознаками адміністративного правопорушення є: протиправна дія чи бездіяльність (ознака, що характеризує об'єктивну сторону), яка посягає на громадський порядок, власність, права $i$ свободи громадян, на встановлений порядок управління (ознака, що характеризує об'єкт правопорушення).

Об'єктом адміністративного правопорушення визначено суспільні відносини, встановлені нормами адміністративного та інших галузей законодавства, яким адміністративним правопорушенням завдається або може бути завдано шкоди. Загальним об'єктом адміністративного правопорушення, передбаченого cm. 1633 КУпАП? є суспільні відносини у сфері громадського порядку, власності, прав і свобод громадян, установлений порядок управління.

Родовим об'єктом правопорушення, передбаченого ст. 1633 КУпАП? є суспільні відносини державного управління у галузях фбінансів $i$ підприємницької діяльності.

Безпосереднім об'єктом адміністративного правопорушення, передбаченого ст. 1633 КУпАП? є суспільні відносини, встановлені нормами адміністративного ц̆ податкового законодавства між посадовими особами органів державної податкової служби та посадовими органами підприємств, установ, організачій, включаючи установи Національного банку Украӥни, комерційні банки та інші бінансово-кредитні установи з приводу відомостей, зазначених у п. 20.1. Податкового кодексу України. Додатковим об'єктом досліджуваного адміністративного проступку можуть виступати суспільні відносини у сфері оподаткування.

Ключові слова: склад правопорушення, об'єкт, невиконання, законність, вимога, посадова особа, податкові органи.

\section{Актуальність теми}

Адміністративна відповідальність за невиконання законних вимог посадових осіб органів державної податкової служби передбачена ст. $163^{3}$ Кодексу України про адміністративні правопорушення. Проте, у зв'язку з набуттям чинності Податковим кодексом України багато проблем у цій сфері загострилося, зокрема, це обумовлено змінами у визначенні правового статусу посадових (службових) осіб органів Державної податкової служби, особливо такого його важливого елемента? як права.

Аналіз останніх досліджень і публікацій

До проблем адміністративно-правового забезпечення діяльності органів Державної податкової служби України звертались 
такі вчені? як О.М. Бандурка, А.I. Берлач, В.Т. Білоус, Ю.П. Битяк, І.П. Голосніченко, Р.А. Калюжний, С.В. Ківалов, М.В. Коваль, В.К. Колпаков, А.Т. Комзюк, О.В. Кузьменко, О.П. Рябченко, С.Г. Стеценко, В.М. Столбовий, В.К. Шкарупа та інші. Проте питання складу правопорушення у виді невиконання законних вимог посадових осіб органів Державної податкової служби України досліджені у недостатній мірі.

У зв'язку із цим, метою запропонованої статті є визначення об'єкту правопорушення у виді невиконання законних вимог посадових осіб органів Державної податкової служби України.

\section{Виклад основного матеріалу}

Чинне адміністративне законодавство, крім визначення поняття адміністративного правопорушення (ст. 9 КУпАП), не виділяє об'єктивних ознак адміністративного правопорушення. Проте із визначення поняття адміністративного правопорушення можна зробити висновок, що обов’ язковими ознаками адміністративного правопорушення є: протиправна дія чи бездіяльність (ознака, що характеризує об'єктивну сторону), яка посягає на громадський порядок, власність, права і свободи громадян, на встановлений порядок управління (ознака, що характеризує об'єкт правопорушення).

Як зазначають дослідники, об’єкт правопорушення - те, на що воно зазіхає, які суспільні відносини порушує. Загальний об'єкт визначається завданнями законодавства про адміністративну відповідальність (ст. 1 КУпАП), а також тими ознаками, за допомогою яких законодавець формулює поняття адміністративного правопорушення (ст. 9 КУПАП). Фактично таким об'єктом виступають суспільні відносини у сфері державного управління, які охороняються заходами адміністративної відповідальності. Насамперед - це управлінські суспільні відносини, які врегульовані нормами адміністративного права. Однак не можна забувати про те, що адміністративні правопорушення фактично зазіхають і на інші суспільні відносини (урегульовані, наприклад, нормами конституційного, фінансового, трудового права), які охороняються також адміністративно-правовими засобами. Отже, загальний об'єкт адміністративних правопорушень більш широкий від власне управлінських відносин [1, с. 144].

Також поширеним є визначення об'єкта адміністративного правопорушення як суспільних відносин, що врегульовані нормами адміністративного права, яким завдано шкоди адміністративним правопорушенням. Іншими словами, це те, на що спрямовано адміністративне правопорушення [2, с. 234]

Вважаємо, що таке визначення має суттєву ваду, адже суспільні відносини, які знаходяться під охороною адміністративного права, можуть регулюватися не лише нормами адміністративного законодавства, а й нормами інших галузей законодавства (наприклад, у контексті ст. $166^{3}$ КУпАП податкового).

Враховуючи викладене, вважаємо, що об'єктом адміністративного правопорушення є суспільні відносини, встановлені нормами адміністративного та інших галузей законодавства, яким адміністративним правопорушенням завдається або може бути завдано шкоди.

У теорії адміністративного права зазвичай розрізняють загальний, родовий та безпосередній об'єкт адміністративного правопорушення. Така трьохступенева класифікація об'єкту протизаконного проступку є найбільш поширеною також у теорії кримінального права. Так, на думку В.Я. Тація, трьохступенева класифікація об’єкта проступку є найбільш вдалою. Відповідно до трьохступеневої класифікації об'єкта виокремлюють: загальний, родовий та безпосередній об'єкт злочину чи адміністративного проступку [3, с. 211-212].

Хоча окремі автори в такій класифікації виділяють серед інших також видовий об'єкт адміністративного правопорушення [4, с. 48]. Видовий об’єкт адміністративного правопорушення - різновид родового об'єкта, відособлена група суспільних відносин, спільна для ряду проступків [5, с. 49].P. I. Михайлов звертає увагу на те, що визначення видового об'єкта адміністратив- 


\section{Адміністративне право}

ного делікту має конкретну практичну спрямованість. Воно необхідно для правильної кваліфікації адміністративних проступків, оскільки в цьому випадку враховуються особливості об'єкта певного виду проступків [6, с. 173].

Слушно зазначає Д. В. Рудник, що чотирьохступенева класифікація об'єкта проступку є найбільш вдалою як 3 наукової, так і суто практичної точок зору. На тій підставі, що у національному праві не існує єдиного, уніфікованого нормативного акту, який передбачає адміністративну відповідальність, норми, що передбачають адміністративну відповідальність, містяться у багатьох Законах України та кодексах, використання видового об'єкту проступку дозволить об'єднати норми, що передбачають адміністративну відповідальність 3 метою правильної кваліфікації та проведення наукового аналізу. Крім того, слід зазначити, що у деяких країнах світу використовується чотирьохступенева класифікація для побудови кримінального та адміністративноделіктного законодавства [7, с. 348]. Проте, вважаємо, що наведені точки зору щодо виділення у класифікації об'єкта проступку видового об'єкта полегшують праворозуміння, але з точки зору правозастосування є зайвою конкретизацією суспільних відносин, що утворюють родовий об'єкт.

Поняття загального об'єкта адміністративного правопорушення, як правило, розкривають як сукупність суспільних відносин, які охороняються законодавством про адміністративні правопорушення [8, c. 163]. Що ж до родового об'єкта, то його розуміють як однорідну групу суспільних відносин, на які посягають адміністративні правопорушення. I в залежності від родового об'єкта посягання адміністративні проступки розміщені за главами в Особливій частині КУпАП [9, с. 61]

Загальним об'єктом є сукупність суспільних відносин, встановлених нормами адміністративного права. Виходячи з цього, загальним об'єктом адміністративного правопорушення, передбаченого ст. $163^{3}$ КУпАП, є суспільні відносини у сфері громадського порядку, власності, прав і свобод громадян, установлений порядок управління.
Тобто ми підтримуємо наведену позицію авторів, які вважають, що загальним об'єктом адміністративного правопорушення $є$ вся сукупність суспільних відносин, які законодавцем поставлені під охорону нормами адміністративного права.

Родовим об'єктом адміністративного проступку науковці вважають однорідну сукупність суспільних відносин, які пов'язані між собою на підставі: охорони спільних суспільно корисних інституцій, їх змісту тощо. При кодифікації адміністративно деліктного законодавства для класифікації всього масиву складів адміністративних проступків по окремих главах Особливої частини розділу II КУпАП законодавець зробив це на підставі родового об'єкта адміністративного проступку. Однак деякі автори піддають критиці структуру КУпАП, мотивуючи це тим, що споріднені на підставі родового об'єкту делікти знаходяться у різних главах КУпАП [10, с. 76].

Родовим об'єктом є група однорідних суспільних відносин, встановлених нормами адміністративного права. Родовим об'єктом щодо досліджуваної норми(ст. $163^{3}$ КУпАП) є суспільні відносини державного управління у галузях торгівлі, громадського харчування, сфері послуг, у галузі фінансів і підприємницької діяльності. На нашу думку, таке поєднання багатьох сфер суспільних відносин в одній главі є термінологічно неправильним й суперечить основним вимогам законодавчої техніки [11, с. 37].

Вважаємо, що в плані удосконалення законодавства таку сферу суспільних відносин, як фінансів і підприємницької діяльності, доцільно було $б$ виділити в окрему главу.

Найбільш важливим для правозастосування є безпосередній об'єкт адміністративного правопорушення або конкретні суспільні відносини, встановлені нормами адміністративного права, яким правопорушенням завдається або може бути завдана шкода. Наприклад, на думку авторів науково-практичного коментаря до КУпАП, об'єктом правопорушення, передбаченого ст. $163^{3}$ КУПАП, є суспільні відносини „у сфері державного управління та у сфері 
оподаткування" [12, с. 289]. Підтримати або спростувати дане визначення можна лише на підставі аналізу структури суспільних відносин, які охороняються даною нормою.

У теорії права загальновизнаною є позиція, що безпосереднім об'єктом будьякого правопорушення, навіть злочину, є суспільні відносини. Заради справедливості слід зазначити, що така дефініція зазнавала численних спроб перегляду на користь того чи іншого означення, а саме - блага, яке охороняється законом, суспільного інтересу та інше. Водночас, формула „безпосередній об'єкт - суспільні відносини", доведена часом, а також випливає із структури суспільних відносин, яка, у свою чергу, складається з суб'єктів таких відносин, предмета, з приводу якого такі відносини виникають, соціального зв'язку між суб'єктами суспільних відносин.

Проаналізувавши суспільні відносини, які поставлені законодавцем під охорону ст. $163^{3}$ КУпАП, крізь призму їх елементів, можна визначити поняття безпосереднього об'єкта цього правопорушення.

Суб'єктами суспільних відносин щодо розглядуваної статті $є$ : посадові особи органів державної податкової служби, які наділені повноваженнями здійснювати державне управління у сфері оподаткування відповідно до положень Податкового кодексу України та інших нормативно-правових актів; посадові особи підприємств, установ, організацій, включаючи установи Національного банку України, комерційні банки та інші фінансово-кредитні установи (повноваження яких визначені Законом України „Про Національний банк України”, Законом України „Про банки і банківську діяльність", підзаконними нормативно-правовими актами, посадовими інструкціями тощо).

У загальному розумінні, предметом суспільних відносин $є$ те, 3 приводу чого ці суспільні відносини виникають. У нашому випадку предметом суспільних відносин державного управління у сфері оподаткування є відомості:

- від платників податків, а також від установ Національного банку України та комерційних банків щодо банківських рахунків та їх обсягів коштів на них;

- відомості для формування інформаційного фонду Державного реєстру фізичних осіб - платників податків та зборів (обов'язкових платежів) від платників податків, а також Національного банку України та його установ - про суми доходів, виплачених фізичним особам, і утриманих 3 них податків та зборів (обов'язкових платежів);

- відомості від органів, уповноважених проводити державну реєстрацію суб'єктів, а також видавати ліцензії на провадження видів господарської діяльності, що підлягають ліцензуванню відповідно до закону, - про видачу таких свідоцтв про державну реєстрацію та ліцензій суб'єктам господарської діяльності;

- відомості від органів внутрішніх справ - про громадян, які прибули на проживання до відповідного населеного пункту чи вибули з нього;

- відомості від органів реєстрації актів громадянського стану - про громадян, які померли;

- відомості від митних органів про ввезення на митну територію України імпортних товарів і справляння при цьому податків та зборів (обов'язкових платежів) та відомості про експортно-імпортні операції, що здійснюють резиденти і нерезиденти, за формою, погодженою 3 Державною податковою адміністрацією України;

- відомості від органів статистики, необхідні для використання їх у проведенні аналізу фінансово-господарської діяльності підприємств, установ, організацій усіх форм власності.

Під соціальним зв'язком розуміють відносини між суб'єктами з приводу предмета. У нашому випадку такими відносинами будуть управлінські відносини у сфері оподаткування між посадовими особами органів державної податкової служби та посадовими органами підприємств, установ, організацій, включаючи установи Національного банку України, комерційні банки та інші фінансово-кредитні установи 3 приводу вказаних вище відомостей. 


\section{Адміністративне право}

Звідси, безпосереднім об'єктом адміністративного правопорушення, передбаченого ст. $163^{3}$ КУпАП, є суспільні відносини, встановлені нормами адміністративного й податкового законодавства між посадовими особами органів державної податкової служби та посадовими органами підприємств, установ, організацій, включаючи установи Національного банку України, комерційні банки та інші фінансово-кредитні установи з приводу відомостей, зазначених у п. 20.1. Податкового кодексу України.

Проаналізовані нами постанови судів, відповідно до яких особи притягуються до адміністративної відповідальності за статтею $163^{3}$ КУпАП, а також протоколи, складені посадовими та службовими особами органів ДПС України, свідчать про те, що у правозастосовній діяльності об'єкт цього адміністративного правопорушення, як правило, не описується. Разом 3 тим, ми вважаємо, що така позиція є не зовсім правильною адже, встановивши лише всі об'єктивні та суб'єктивні ознаки, можна дійти висновку щодо наявності складу адміністративного правопорушення (що підтверджується наведеними вище матеріалами практики).

Поряд 3 класифікацією об'єкта адміністративного проступку по „вертикалі” теорія адміністративно деліктного права проводить класифікацію об'єктів адміністративних деліктів по „горизонталі”, відповідно до цього поділу наука виокремлює додатковий та факультативний об'єкт адміністративного проступку. Під додатковим об'єктом розуміються суспільні відносини, які в порівнянні з безпосереднім об'єктом проступку відносяться до іншого родового чи видового об'єкту адміністративного проступку й яким шкода завдається завжди під час вчинення адміністративного делікту, факультативний об'єкт відрізняється від додаткового тим, що шкода цим відносинам може не завдаватись під час вчинення проступку.

Саме тому вважаємо, що додатковим об'єктом досліджуваного адміністративного проступку можуть виступати суспільні відносини у сфері оподаткування. Наприклад, 18 червня 2013 року суддя Жовтовод- ського міського суду Дніпропетровської області Хорошенко В.М., розглянувши справу про вчинення адміністративного правопорушення, передбаченого ч.1 ст. 163-3 КУпАП, встановив наступне.

У відповідності 3 вимогами п.1 ст. 75, ст. 77, ст. 82 Податкового Кодексу України наказом №221 від 25.02.2013 р., починаючи 311 березня 2013 року і протягом 20 робочих днів, було призначено проведення планової виїзної перевірки Публічного акціонерного товариства Жовтоводський хлібозавод, розташованого по вул. Залізничній, 2 у м. Жовті Води Дніпропетровської області, з питань дотримання вимог податкового законодавства за період часу 3 01 квітня 2011 року по 31 грудня 2012 року.

На підставі цього наказу 11 березня 2013 року Верхньодніпровською ОДП державним податковим інспекторам Даниленко Н.І., Дідик О.А., Панченку В.І., Радченко В.І. та Аівіцькій А.С. були видані направлення для проведення зазначеної перевірки за №104/222, №105/222, №106/222, № 107/222, № 108/222.

У ході проведення вказаної перевірки директору ПАТ Жовтоводський хлібозавод ОСОБА_2 і головному бухгалтеру цього підприємства ОСОБА_1 під особистий підпис було вручено запити податкових інспекторів №1 від 21.03.2013 р., №2 від 26.03.2012 р., №3 від 29.03.2013 р., №4 від 02.04.2013 р. і №5 від 03.04.2013 р. щодо надання документів (регістрів бухгалтерського обліку та первинних документів), а також пояснень 3 питань формування доходів, витрат та відповідного їх відображення у податковому обліку.

Згідно $з$ п.п.20.1.24. ст.20 Податкового кодексу України такі вимоги посадових осіб органів державної податкової служби є законними і підлягають виконанню.

Однак станом на 04 квітня 2013 року зазначені законні вимоги посадових осіб органів державної виконавчої служби директором підприємства ОСОБА_2 та головним бухгалтером ОСОБА_1 виконано так і не було, а затребувані документи для перевірки так і не надано.

Від підписання протоколу про адміністративне правопорушення, складеного 
державним податковим інспектором-ревізором ОСОБА_3 04 квітня 2013 року, дачі пояснень щодо цього протоколу та отримання його копії ОСОБА_1 відмовився, про що у відповідності до вимог закону податковим інспектором зроблено відповідний запис у протоколі.

Будучи повідомленим про дату, час i місце розгляду справи суддею, ОСОБА_1 до суду також не з'явився, про причини неявки суд не повідомив, власних пояснень чи заперечень не надав.

Водночас вина ОСОБА_1 у невиконанні законних вимог посадових осіб органів державної податкової служби за вказаних вище обставин підтверджується наданими письмовими доказами.

Таким чином, своїми діями ОСОБА_1 вчинив адміністративне правопорушення, передбачене ч.1 ст. 163-3 КУпАП невиконання посадовими особами підприємств законних вимог посадових осіб органів державної податкової служби, перелічених у підпункті 20.1.24, Податкового кодексу України [13].

Вказане порушення виявлено також під час складання матеріалів перевірки, та протоколу Державною податковою інспекцією у Київському районі м. Донецька 19 лютого 2010 року (акт відмови від підписання матеріалів перевірки, від 18.02.2010 року №452〈23-3). Правопорушник до суду не з'явився, про час і місце розгляду справи повідомлявся належним чином, причини неявки не повідомив. Заяв про відкладення розгляду справи від нього не надходило. Як вбачається з протоколу про адміністративне правопорушення, правопорушнику роз'яснені положення ст. 63 Конституції України і ст. 268 КУпАП, про що свідчить його підпис у протоколі. Оскільки правопорушник належним чином повідомлений про час i місце розгляду справи i, враховуючи, що відповідно до ст. 268 КУпАП його присутність при розгляді справи не $є$ обов'язковою, суд вважає за можливе розглянути справу за відсутності правопорушника. Дослідивши акт від 18.02.2010 року №452\23-3, протокол про адміністративне правопорушення від 19.02.2010 р., суд при- ходить до висновку, що К. вчинив правопорушення, передбачене ч. 1 ст. $163^{3}$ КУпАП.

\section{Висновки}

Об'єктом адміністративного правопорушення є суспільні відносини, встановлені нормами адміністративного та інших галузей законодавства, яким адміністративним правопорушенням завдається або може бути завдано шкоди. Загальним об'єктом адміністративного правопорушення, передбаченого ст. $163^{3}$ КУПАП, є суспільні відносини у сфері громадського порядку, власності, прав і свобод громадян, установлений порядок управління.

Родовим об'єктом правопорушення, передбаченого ст. $163^{3}$ КУпАП, є суспільні відносини державного управління у галузях фінансів і підприємницької діяльності.

Безпосереднім об'єктом адміністративного правопорушення, передбаченогост. $163^{3}$ КУпАП, є суспільні відносини, встановлені нормами адміністративного й податкового законодавства між посадовими особами органів державної податкової служби та посадовими органами підприємств, установ, організацій, включаючи установи Національного банку України, комерційні банки та інші фінансово-кредитні установи з приводу відомостей, зазначених у п. 20.1. Податкового кодексу України. Додатковим об'єктом досліджуваного адміністративного проступку можуть виступати суспільні відносини у сфері оподаткування.

Визначення об'єкта та предмета адміністративного проступку, передбаченогост. $163^{3}$ КУПАП, є основою для правильного встановлення всіх ознак об'єктивної сторони цього правопорушення.

\section{入iтература}

1. Шкарупа В. К., Коваль М. В.,Савчук О. П. Самофалов Л. П., Мацелик М. О. Адміністративне право України: Конспект лекцій. Ірпінь: Національна академія ДПС України, 2005. 248 с.

2. Стеценко С. Г. Адміністративне право України: Навчальний посібник. - Вид. 2-ге, перероб. та доп. К.: Атіка, 2009. 640 с. 


\section{Адміністративне право}

3. Юридична енциклопедія: В 6 т. / Редкол.: Ю.С. Шемшученко (відп. ред.) та ін. К.: «Укр. енцикл.», 2003. Т. 5: П-С. 736 с.

4. Бахрах Д. Н. Производство по делам об административных правонарушениях. М. : Знание, 1989. 96 с.

5. Бахрах Д.Н. Административная ответственность граждан в СССР : учеб, пособ. Свердловск: Изд-во Урал, ун-та, 1989. $204 \mathrm{c}$.

6. Михайлов Р. І. Характеристика складу адміністративних деліктів у сфері забезпечення безпеки дорожнього руху. Держава та регіони: Серія: Право. 2010. № 3. C. 172-177.

7. Рудник Д. В. Питання про класифікацію об'єкта адміністративних деліктів у сфері випуску та обігу цінних паперів. Ученъе записки Таврического начионального университета им. В. И. Вернадского Серия «Юридические науки». 2008. Том 21 (60). № 2. C. 347-352.

8. Битяк Ю. П., Зуй В. В. Административное право Украины (Общая часть): учеб. пособ. Харьков: ООО «Одиссей», 1999. 233 с.

9. Миколенко А. И. Административный процесс и административная ответственность в Украине : учеб, пособие. Х. : Одиссей, 2004. 270 с.

10. Загуменник В. Адміністративна відповідальність. Проблеми та шляхи іiі подолання. Вісник прокуратури. - 2008. № $2(80)$. - С. $70-77$.

11. Керимов Д. А. Законодательная техника. Научно-методическое и учебное пособие. М. : Издательство НОРМА, 2000. $127 \mathrm{c}$.

12. Калюжний Р.А., Комзюк А.Т., Погрібний О.О. та ін. Кодекс України про адміністративні правопорушення: Науковопрактичний коментар. Видання третє. К.: Алерта; КНТ; ЦУЛ, 2010. 684 с.

13. Постанова Жовтоводського міського суду Дніпропетровської області (Справа №176/1542/13-п). Державний реєстр судових рішень. URL : http://www.reyestr.court. gov.ua/Review/48627751.

SUMMARY

The article is devoted to the definition of the object of the offense in the form of failure to comply with the legal requirements of tax officials. It is noted that the current administrative legislation, in addition to defining the concept of an administrative offense (Article 9 of the Code of Administrative Offenses), does not distinguish objective signs of an administrative offense. However, from the definition of the concept of an administrative offense, we can conclude that the mandatory signs of an administrative offense are: unlawful action or inaction (a sign that characterizes the objective side), encroaching on public order, property, rights and freedoms of citizens, on the established management order (sign that characterizes the object offenses).

The object of an administrative offense is defined by public relations established by the norms of the administrative and other branches of legislation, to which an administrative offense is caused or may be damaged. The general object of an administrative offense under Article 1633 Code of Administrative Offenses are public relations in the field of public order, property, rights and freedoms of citizens, the established management procedure.

The object of the offense under Article 1633 Code of Administrative Offenses are public relations of public administration in the field of finance and business.

The direct object of an administrative offense under 1633 Code of Administrative Offenses are public relations established by the norms of administrative and tax legislation between officials of the state tax service and officials of enterprises, institutions, organizations, including the institutions of the National Bank of Ukraine, commercial banks and other financial and credit institutions regarding the information specified in paragraph. 20.1. Tax Code of Ukraine. An additional object of the investigated administrative misconduct may be public relations in the field of taxation.

Key words: corpus delicti, object, failure to comply with the law, requirement, official, tax authorities. 